\title{
Miscanthus Biomass for Alternative Energy Production
}

\author{
Jikai Zhao, Donghai Wang, Valentina Pidlisnyuk, and Larry E. Erickson
}

\begin{abstract}
Biomass such as Miscanthus that is produced using phytoremediation can be used as a biofuel. In some locations it is used for heating homes that are located close to where it is produced. This chapter considers alternative energy technologies for Miscanthus and other plants, including liquid fuels such as ethanol, methane from anaerobic digestion, and pyrolysis (thermal Processing). Pretreatment alternatives to convert cellulose to glucose are reviewed because the economics of ethanol production from Miscanthus are impacted by the efficiency of cellulose hydrolysis to glucose. Size reduction of Miscanthus is often the first step in the process because enzymes for hydrolysis are more effective when there is large surface area. Ethanol that is produced by fermentation as a liquid is easier and less expensive to transport compared to Miscanthus biomass and methane from anaerobic digestion. Methane that is produced by anaerobic digestion is a mixture of methane and carbon dioxide. It can be used locally as a fuel, but it is expensive to distribute over a significant distance by pipeline. This chapter reviews pretreatment methods for Miscanthus prior to anaerobic digestion. There is a need to make good use of the hemicellulose and lignin because the economics are better when all of the harvested Miscanthus is used with good conversion efficiency.
\end{abstract}

\section{CONTENTS}

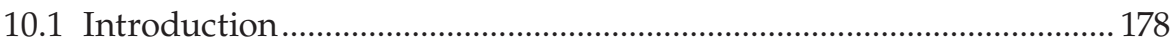

10.2 Evaluation of Biomass Suitability for Energy …………...................... 178

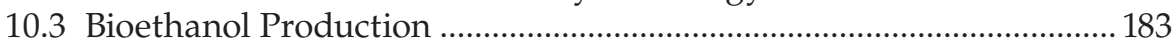

10.3.1 Physicochemical Pretreatment.................................................... 183

10.3.2 Enzymatic Hydrolysis and Fermentation ................................... 185

10.4 Biomethane and Biohydrogen Production .............................................. 186

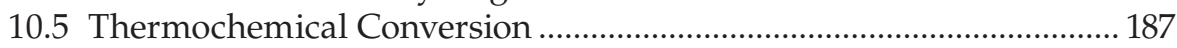

10.5.1 Heat and Power Generation ................................................... 187

10.5.2 Bio-Oil and Syngas Production …………….............................. 189

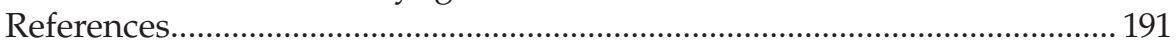




\subsection{Introduction}

The gradual depletion of nonrenewable fossil fuels and environmental deterioration due to the growing demand for energy sources and concern over greenhouse gas emissions have attracted considerable attention to exploring renewable and sustainable biofuels and supporting sustainable economic development (Arnoult \& Brancourt-Hulmel, 2015). Lignocellulosic biomass, mainly composed of carbohydrate polymers (cellulose and hemicellulose) and an aromatic polymer (lignin), is widely identified as a promising alternative with great potential for biofuels production (Ho et al., 2019; Kim et al., 2016). Biological conversion of lignocellulosic biomass into ethanol, methane, hydrogen, heat, power, bio-oil, and syngas can reduce overdependence on petroleum-based fuels and mitigate climatic change (Brosse et al., 2012; Ge et al., 2016; Ziolkowska, 2014). In particular, bioethanol derived from lignocellulosic biomass has been utilized as a substitutive transportation biofuel to conventional gasoline (Bailey, 2018; von Blottnitz \& Curran, 2007; Wyman, 2008).

The biomass of the second-generation crops including Miscanthus is processed to energy through distinct conversion routes: thermochemical and biochemical (Damartzis \& Zabaniotou, 2011). The thermochemical route consists of the pyrolysis and/or gasification and subsequent gas cleaning and conditioning processes, followed by the Fischer-Tropsch synthesis for the production of synthetic liquid fuels. The biochemical route involves the enzymatic transformation of cellulose and hemicellulose to sugars and subsequent fermentation to bioethanol. The second route, although having more cost reduction potential due to its most recent development and constant effort for optimization, is less prone to commercialization than the first alternative. These two main pathways of biomass processing are illustrated in Figure 10.1.

The differences among the thermochemical processes are determined by the operation conditions of feed properties, oxidizer (air, oxygen or steam) amount, temperature, heating rate, and residence time.

\subsection{Evaluation of Biomass Suitability for Energy}

The key criteria for evaluating the suitability of plants as a raw material for combustion are the amount of biomass from 1 ha of cultivation, the amount of heat obtainable per unit weight of biomass, the cost of establishment of plantation, and the content of mineral substances determined as ash. The amount 


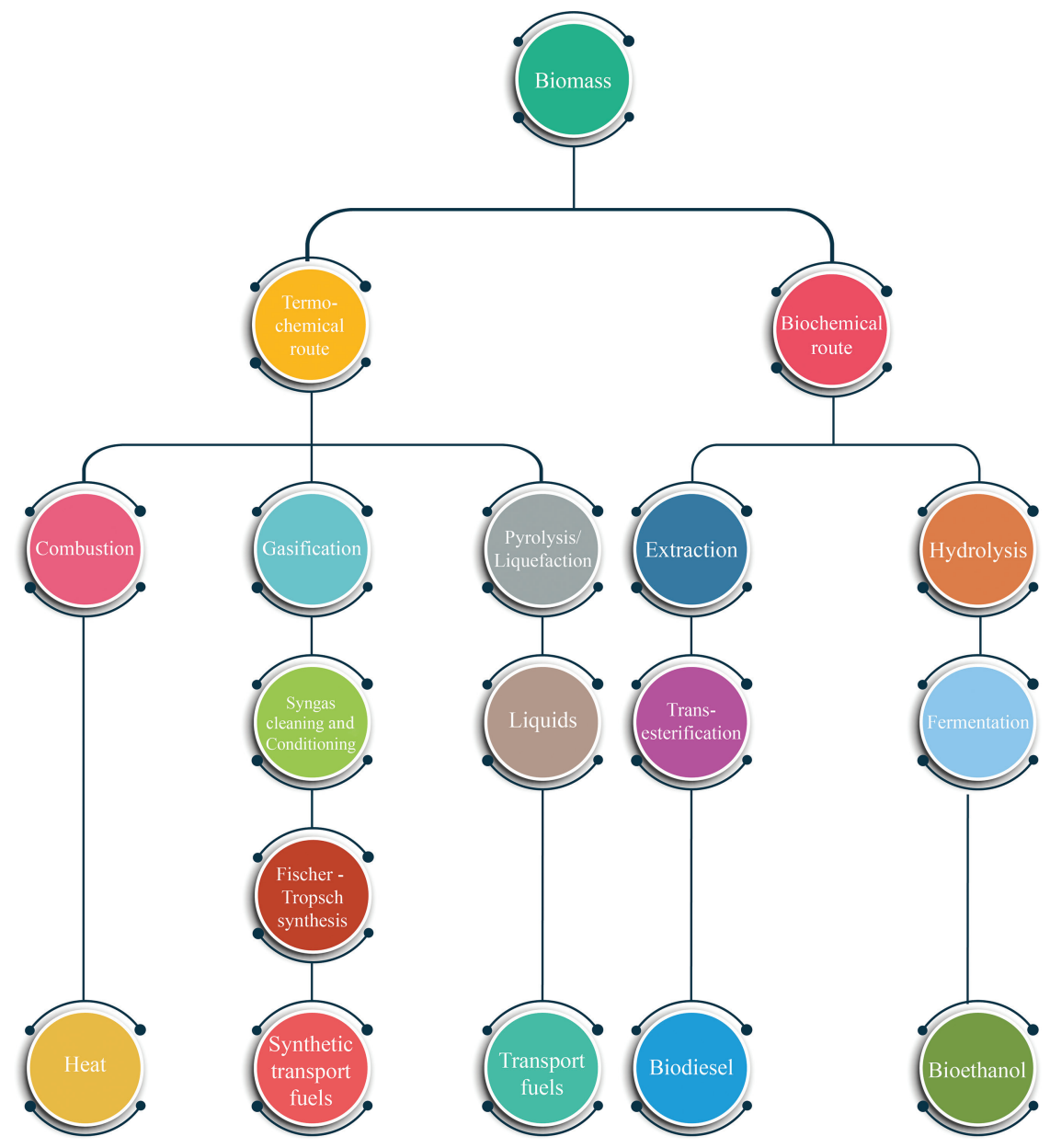

FIGURE 10.1

Schematic illustration of the main biofuel production pathways. (Modified from Damartzis \& Zabaniotou, 2011.)

of biomass yield and the heating value for some grass plants are illustrated in Table 10.1.

Miscanthus as a rhizomatous $\mathrm{C}_{4}$ perennial grass with low maintenance, rapid $\mathrm{CO}_{2}$ absorption, significant carbon sequestration, and high biomass yield characteristics has been regarded as a dedicated energy crop for biofuels production, especially in Europe and North America (Ge et al., 2016; Hastings et al., 2009; Heaton et al., 2008; Lee \& Kuan, 2015; Zub \& BrancourtHulmel, 2010). The yield and chemical composition of Miscanthus biomass 


\section{TABLE 10.1}

Biomass Yield from Grass Crops, Calorific Value, and the Cost of Cultivation

\begin{tabular}{lcc}
\hline Plant Species & Biomass Yield $\left(\mathbf{t ~ h a} \mathbf{a}^{-1}\right)$ & Heating Value $\left(\mathbf{M J ~} \mathbf{~ g g}^{-1}\right)$ \\
\hline Tall wheatgrass & $6.6-10.4$ & 17.89 \\
Tall oatgrass & $7.5-12.4$ & 18.29 \\
Miscanthus & $12.2-21.6$ & 18.56 \\
\hline
\end{tabular}

Source: Modified from Danielewicz et al. (2015).

are commonly influenced by the cultivation site, growing conditions, and harvest time (Arnoult et al., 2015; Kim et al., 2012; Le Ngoc Huyen et al., 2010), thus resulting in significant variation in bioconversion performance (Boakye-Boaten et al., 2016; Hodgson et al., 2010; Iqbal \& Lewandowski, 2014). The heterogeneous nature of Miscanthus biomass allows its bioconversion into several added-value biofuels. For bioethanol production, pretreatment is an essential step to reduce the recalcitrance of biomass, rendering cellulose more amenable and accessible to enzymes (Lee \& Kuan, 2015; Sun et al., 2016).

Anaerobic digestion and dark fermentation are usually used to convert Miscanthus biomass to biomethane and biohydrogen (de Vrije et al., 2009; Vasco-Correa \& Li, 2015). During anaerobic digestion, anaerobic microbes can convert organic matter: pentose and hexose into biogas, methane and carbon dioxide (Frigon \& Guiot, 2010). Dark fermentation is carried out under anaerobic conditions in which heterotrophic microorganisms degrade sugars by oxidation (Guo et al., 2010). The enzymatic attack of the microorganisms directly limits biomethane and biohydrogen production from lignocellulosic biomass. Appropriate pretreatment conditions are often required to accelerate conversion efficiency, including mechanical, thermochemical, and fungal methods (Frigon \& Guiot, 2010; Guo et al., 2010). The potential of biogas production can also be affected by genotypes, harvesting time, and growing season (Mangold et al., 2019; Schmidt et al., 2018; Wahid et al., 2015).

At high temperatures, Miscanthus biomass can be subjected to thermochemical pretreatment to produce heat, power, bio-oil, and biogas that are compatible with current petrochemical infrastructures (Liu et al., 2017). Research findings indicate that operational temperature was the most influential factor in the yield and properties of bio-oil (Heo et al., 2010). Also, specific thermochemical reactors (fluidized bed, spouted bed, and fixed bed) assisted with catalytic and surfactant additives have been used to improve the conversion yield and quality of biofuels (Banks et al., 2014; Melligan et al., 2011; Yorgun \& Şimşek, 2008). In this chapter, the biomass yield and chemical composition of Miscanthus biomass are summarized. The intrinsic mechanism of representative pretreatment methods used for bioethanol, biomethane, and biohydrogen production is thoroughly explained. Thermochemical 
conversion (combustion, pyrolysis, and gasification) of Miscanthus biomass to heat, power, bio-oil, and syngas is also presented. In addition, the internal and external factors that have significant influences on anaerobic digestion and thermochemical conversion performances of Miscanthus biomass are discussed. The flowchart for Miscanthus biomass conversion to different biofuels is illustrated in Figure 10.2.

The management practices for Miscanthus production (soil nutrient composition, amendments, irrigation, climate (precipitation, temperature)) are directly correlated with the properties of biomass and its potential for biofuel production (Cerazy-Waliszewska et al., 2019; Frydendal-Nielsen et al., 2016; Mangold et al., 2019; Wahid et al., 2015).

Representative studies on the chemical compositions of Miscanthus biomass are summarized in Table 10.2. Significant variations were identified in cellulose, hemicellulose, and lignin between the Miscanthus biomass samples, i.e., it is for cellulose $31.0-46.0 \%$, for hemicellulose $13.6-35.4 \%$, and for lignin $10.7-26.7 \%$.

A comparison of chemical characteristics reveals differences in intrinsic genotypes, cultivation conditions, and harvesting times (Alam et al., 2019; Kim et al., 2012; Le Ngoc Huyen et al., 2010). Cellulose (D-glucose polymer) condenses through $\beta$ (1-4) glycosidic bonds (Updegraff, 1969). Robust

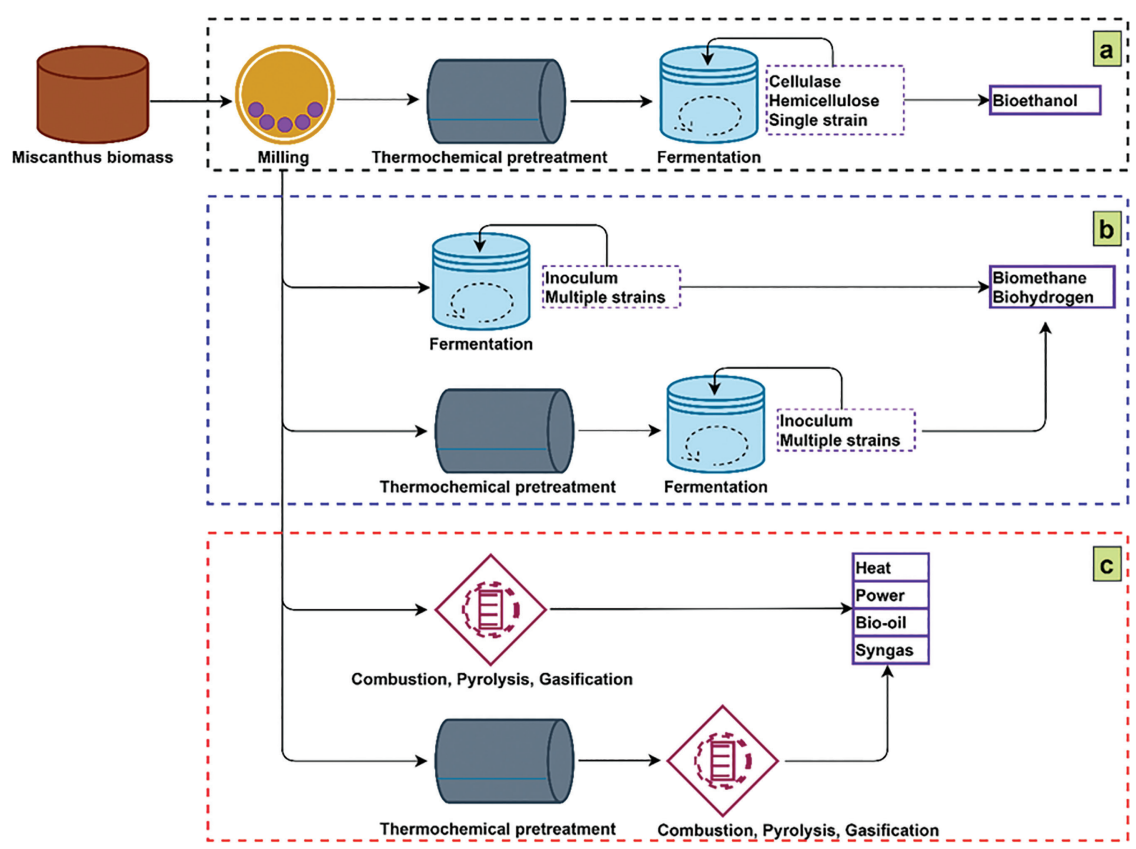

FIGURE 10.2

Flowchart of Miscanthus biomass conversion into biofuels: (a) bioethanol; (b) biomethane and biohydrogen; and (c) heat, power, bio-oil, and syngas. 


\section{TABLE 10.2}

Chemical Composition of Miscanthus Biomass

\begin{tabular}{|c|c|c|c|}
\hline \multicolumn{3}{|c|}{ Composition (\%, Dry Basis) } & \multirow[b]{2}{*}{ Reference } \\
\hline Cellulose & Hemicellulose & Lignin & \\
\hline 46.0 & 27.8 & 10.7 & Wang et al. (2010) \\
\hline 44.4 & 29.1 & 20.4 & Alam et al. (2019) \\
\hline 44.3 & 30.3 & 21.7 & Alam et al. (2019) \\
\hline 44.1 & 29.4 & 22.7 & Alam et al. (2019) \\
\hline 43.3 & 13.6 & 26.3 & Dash and Mohanty (2019) \\
\hline 43.1 & 23.6 & 26.3 & Yang et al. (2015a) \\
\hline 41.2 & 21.2 & 25.1 & Kang et al. (2013) \\
\hline 40.3 & 24.1 & 24.1 & Cha et al. (2015b) \\
\hline 39.7 & 29.0 & 20.2 & Alam et al. (2019) \\
\hline 39.5 & 30.5 & 22.0 & Alam et al. (2019) \\
\hline 39.3 & 29.5 & 19.2 & Alam et al. (2019) \\
\hline 39.2 & 23.5 & 21.4 & Li et al. (2013) \\
\hline 38.6 & 17.9 & 25.4 & Han et al. (2014) \\
\hline 38.0 & 18.5 & 20.9 & Vasco-Correa et al. (2016) \\
\hline 37.2 & 30.9 & 21.9 & Alam et al. (2019) \\
\hline 37.1 & 27.4 & 21.5 & Alam et al. (2019) \\
\hline 37.0 & 22.1 & 23.3 & Han et al. (2011) \\
\hline 36.3 & 22.8 & 21.3 & Boakye-Boaten et al. (2015 \\
\hline 31.5 & 29.2 & 26.7 & Si et al. (2015) \\
\hline 31.0 & 35.4 & 25.3 & Si et al. (2015) \\
\hline 31.0 & 32.8 & 25.6 & Si et al. (2015) \\
\hline
\end{tabular}

hydrogen bonds between and within cellulose strands are attributed to its high crystallinity. Miscanthus biomass is rich in cellulose $(31.0 \%-46.0 \%)$ (Table 10.2). Taking into consideration that the removal of hemicellulose and lignin during the pretreatment process can lead to an approximate two-fold concentration of the remaining cellulose in pretreated biomass, high cellulose content in raw Miscanthus biomass would benefit the fermentable sugar concentration and final bioethanol titer. Hemicellulose (D-pentose polymer), a heterogeneous polysaccharide mix, is mainly composed of a $\beta$-D-xylose monomer in Miscanthus biomass, ranging from $13.6 \%$ to $35.4 \%$ (Table 10.2). Moreover, the hemicellulose is associated with the chemical and physical characteristics of subsequent biofuel. For example, the solubilization and elimination of hemicellulose are often critical to pretreatment effectiveness to increase enzymatic accessibility to cellulose (Zhao et al., 2020a). In the case of the lignin complex, it is randomly methoxylated and incorporated by lignols ( $p$-coumaryl alcohol, coniferyl alcohol, and sinapyl alcohol). Lignin content in Miscanthus biomass is in the range of $10.7 \%-26.7 \%$. Its lower free radicals make it more inert and could form nonproductive hydrophobic interaction with cellulase, thus reducing sugar and bioethanol yields. 


\subsection{Bioethanol Production}

Several studies have reported using various pretreatment steps to reduce the recalcitrance of Miscanthus biomass for the valorization of macromolecules (Brosse et al., 2012; Ge et al., 2016). Miscanthus biomass is characterized by complex components, composing of cellulose, hemicellulose, and lignin (Zub \& Brancourt-Hulmel, 2010). Therefore, an optimal combination of various pretreatment strategies is essential for efficient fractionation and further bioethanol production. The processing methods include mechanical treatment to improve the biomass maneuverability, thermochemical steps for the disruption and solubilization of unproductive compounds, and subsequent enzymatic hydrolysis and fermentation (Figure 10.1). The effectiveness of such processing procedures on the chemical composition, sugar recoveries, inhibitor formation, lignin removal, and bioethanol production performances is summarized and discussed in the following subsections.

\subsubsection{Physicochemical Pretreatment}

The reduction of particle size by mechanical chopping, grinding, or milling is often an initial pretreatment step of the solid starting feedstocks to facilitate subsequent thermochemical or enzymatic hydrolysis and fermentation disrupting their structural regularity and reducing the degree of crystallinity and polymerization (Hendriks \& Zeeman, 2009). Generally, small particle sizes are preferred for efficient enzymatic hydrolysis due to their specific surface area, i.e., sugar accessibility. The particle size distribution is directly associated with chemical composition, sugar recoveries, delignification, and fermentation performances (Khullar et al., 2013). Generally, mechanical treatment by itself is incapable of disrupting and depolymerizing lignin that seals cellulose and hemicellulose tightly (Sun et al., 2016). Many thermochemical methods to conduct after preliminary size reduction have been investigated, including either the utilization of concentrated and dilute acid and alkali (Alam et al., 2019; Scordia et al., 2013; Si et al., 2015; Yoo et al., 2016; Zhao et al., 2020b), liquid hot water (LHW) and steam explosion (Li et al., 2013; Yeh et al., 2016), organosolv and ionic liquids (Brosse et al., 2009; Dash \& Mohanty, 2019; Kim et al., 2018), or a combination of processing (Auxenfans et al., 2014; Rodríguez et al., 2011; Wang et al., 2010; Zhu et al., 2015). However, depending on the pretreatment conditions, various components might be formed as inhibitors that limit enzymatic activity.

Dilute acid (organic and inorganic acids) and alkali (metal hydroxide and aqueous ammonia) pretreatments have been extensively explored to enhance the enzymatic digestibility of Miscanthus biomass (Alam et al., 2019; Ji et al., 2015; Si et al., 2015; Vanderghem et al., 2012; Yoo et al., 2016). Since glucosidic bonds of cellulose and hemicellulose are susceptible to acid, a high 
proportion of hemicellulose and some of cellulose are hydrolyzed into slurries during pretreatment, and sugar degradation compounds such as furfural and hydroxymethylfurfural (HMF) as well as aromatic lignin degradation compounds can be generated (Mosier et al., 2005; Zhao et al., 2020a). Dilute acid pretreatment is commonly performed with high temperature $\left(>150^{\circ} \mathrm{C}\right)$ and short time ( $<1$ hour). Moreover, ethanol yield depends on pretreatment conditions applied (acid dose, reaction time, and temperature) (Ji et al., 2015). Alkali pretreatment can efficiently cleave and decompose the chemical crosslinks (ether and ester bonds) between carbohydrates and lignin, resulting in a structural alteration of lignin and elimination of hemicellulose (Zhao et al., 2020b). The solubilization of disrupted lignin and hemicellulose renders Miscanthus biomass more amenable to enzymes due to the increment of cellulosic accessibility. Furthermore, alkali pretreatment is conducted under relatively low temperatures but long residence times, followed by multiplewashing for removing small lignin units and other inhibitors.

LHW and steam explosion as the category of hydrothermal pretreatments have attracted considerable attention for pretreatment of lignocellulosic biomass and solubilization of amorphous hemicellulose. During pretreatment, water can be autoionized into acidic hydronium ions that cleave the glycosidic bonds of hemicellulose, resulting in the formation of acetic acid, which in turn catalyzes breaking cellulose and hemicellulose into oligosaccharides and monomeric sugars (glucose and xylose) (Mosier et al., 2005). Thus, harsh pretreatment temperatures $\left(180^{\circ} \mathrm{C}-230^{\circ} \mathrm{C}\right)$ induced further degradation and decomposition of monosaccharides into inhibitors (e.g., furfural and HMF) (Li et al., 2013). The formation of inhibitors in hydrolysates can cause sugar loss and inhibit subsequent enzymatic hydrolysis and fermentation. Thus, the detoxification process is commonly needed. Also, since the cellulose and lignin are more robust than hemicellulose, they are amenable for recovery. Therefore, hydrophobic interaction between residual lignin and cellulose during enzymatic saccharification is inevitable if there is no surfactant addition.

Organosolv and ionic liquids as green solvents offer the advantage of clean fractionation of lignocellulosic biomass into individual components with high purity (Brosse et al., 2009; Dash \& Mohanty, 2019; Kim et al., 2018). Organosolv allows for the efficient fractionation of starting biomass into a solid residue rich in cellulose and a liquid fraction containing organosolv and water-soluble lignin and hemicellulose (Brosse et al., 2009). Ionic liquids owing hydrogen bond acceptor with high polarity can dissolve Miscanthus biomass, and ionic liquids having acetate, chloride, and phosphate anions show desirable solubility properties (Padmanabhan et al., 2011). However, excessive reagents are consumed for washing pretreated biomass to avoid lignin recondensation. Besides, the sealed condition required for organosolv and ionic liquid recoveries increases production costs, limiting their feasibility in commercialization.

To compensate for the drawbacks of a single pretreatment, the physical and chemical combinations such as microwave-assisted with acid and alkali 
(Zhu et al., 2015), dilute acid presoaking coupled with wet explosion (Sørensen et al., 2008), dilute acid assisted with ionic liquids (Auxenfans et al., 2014), alkaline peroxide and electrolyzed water (Wang et al., 2010), ammonia with ionic liquids (Rodríguez et al., 2011), and aqueous ammonia with electron beam irradiation (Yang et al., 2015b) have been proposed to boost sugar and ethanol yields of Miscanthus biomass. Although some of these approaches, when combined, are potentially efficient for removing lignin and hemicellulose, complicated procedures need extra capital investment and operating costs. Besides, research only demonstrates their feasibility in the laboratory, more industrial or life cycle assessments coupled with detailed process economics are required before commercialization.

\subsubsection{Enzymatic Hydrolysis and Fermentation}

Apart from chemical compositions caused by external and intrinsic elements and pretreatment methods as discussed previously, solid and enzyme loading, surfactant addition, and applied microorganisms are also responsible for enzymatic hydrolysis and fermentation performances of biomass (Vanderghem et al., 2012).

Low solid loading would be beneficial for shortening enzymatic hydrolysis and fermentation duration and reaching high ethanol yield but causing low ethanol titer, which could be unable to meet the minimal requirement (around $40 \mathrm{~g} \mathrm{~L}^{-1}$ ) for commercial ethanol distillation. Simultaneous saccharification and fermentation (SSF) of Miscanthus biomass was commonly conducted at solid loading less than $15 \%$ with the maximum ethanol titer less than $30 \mathrm{~g} \mathrm{~L}^{-1}$ (Cha et al., 2015a; Scordia et al., 2013; Yoo et al., 2016). Given $60 \%$ of cellulose in pretreated Miscanthus biomass and $90 \%$ of glucose-toethanol conversion efficiency, the lowest solid loading for SSF should be greater than $13 \%$ to achieve $40 \mathrm{~g} \mathrm{~L}^{-1}$ of ethanol concentration. Increasing solid loading within certain limits would theoretically enhance ethanol concentration. High solid loading with advantages of high ethanol titer and less water consumption is preferred from cost-efficiency and environmental standpoints (Chen et al., 2016). However, the decrease in glucan-toethanol yield is inevitable due to hydrophobic absorption between lignin and cellulase inhibiting enzymatic absorption and insufficient mixing (Kristensen et al., 2009). Several improvement strategies, such as surfactant addition (Alam et al., 2019), size reduction (Khullar et al., 2013), and thermotolerant microbial strains (Cha et al., 2015a), have been explored to enhance enzymatic saccharification and microbial digestion at high solid loading. However, initial studies aimed only to ferment glucose derived from cellulose using hexose-consuming microbial strains such as Saccharomyces cerevisiae. Recently, modified strains from genetic engineering capable of digesting pentose and hexose simultaneously and pentose-metabolizing bacterial strains of Escherichia coli have been developed to ferment the potential sugars in biomass sufficiently. 


\subsection{Biomethane and Biohydrogen Production}

Biomethane and biohydrogen production is a renewable and sustainable technological process for Miscanthus biomass by anaerobic digestion (Figure 10.1). Compared to grain such as maize, Miscanthus-based biogas presents more economical and environmental advantages (Wagner et al., 2019).

Traditionally, Miscanthus biomass is first subjected to mechanical chopping and inoculated with anaerobic sludge performing SSF at thermophilic and mesophilic conditions (Klimiuk et al., 2010). The sewage or wastewater sludges, crop silages, and animal manures are commonly utilized as inoculum, which is composed of acetogenic bacteria and methanogens (Guo et al., 2010; Kiesel \& Lewandowski, 2017; Klimiuk et al., 2010). During fermentation, biomacromolecules (cellulose and hemicellulose) are hydrolyzed to monomeric sugars (hexose and pentose) and then digested to organic acids and hydrogen by homoacetogens. The acetic acid and hydrogen generated as critical intermediates are rapidly consumed and transformed into $\mathrm{CH}_{4}$ by methanogens (Guo et al., 2010). The potential of Miscanthus biomass for methane production has been reported to differ according to biomass harvest time, genotype, and plant fractions (Mangold et al., 2019; Schmidt et al., 2018; Wahid et al., 2015). This variation is associated with the compositional differences in the starting biomass, which can be mainly reflected by lignin incrustation that slowed down the enzymatic hydrolysis efficiency of polysaccharides (Klimiuk et al., 2010). In the case of fermentation, operational conditions, such as slurry $\mathrm{pH}$, pressure, temperature, and microbial strains, also reflected notable differences in fermentation processes and were directly correlated with the conversion efficiency of carbohydrates to methane and hydrogen (Guo et al., 2010).

For biomethane production, physicochemical pretreatment methods have been often proposed to enhance biomass-to-biogas conversion efficiency by fractionation and decomposition of recalcitrant structures of Miscanthus biomass. Similar to bioethanol production, these mainly include size reduction, ensiling, steam explosion, LHW, acid, alkali, aqueous ammonia soaking, hydrogen peroxide, and enzymatic pretreatments (Jurado et al., 2013; Katukuri et al., 2017; Li et al., 2016; Menardo et al., 2013; Michalska et al., 2015; Nges et al., 2016; Zhou et al., 2017). However, the effectiveness of the pretreatment highly varied with pretreatment methods and conditions. For example, ensiled biomass showed higher methane yield and digestion rate than unensiled biomass (Mangold et al., 2019). Aqueous ammonia soaking increased methane yield by $25 \%-27 \%$ (Jurado et al., 2013), and hydrogen peroxide pretreatment increased methane yield by $49 \%$ (Katukuri et al., 2017). In the case of biohydrogen, one-step extrusion- $\mathrm{NaOH}$ pretreatment at moderate temperature resulted in $77 \%$ delignification and more than $95 \%$ of cellulose recovery as well as enhanced hydrogen yield (de Vrije et al., 2002). Mild alkali pretreatment assisted with Caldicellulosiruptor saccharolyticus and Thermotoga 
neapolitana strains to achieve hydrogen yields of 2.9 to $3.4 \mathrm{~mol} \mathrm{H}_{2}$ per mol of hexose, corresponding with $74 \%-85 \%$ of sugar yield (de Vrije et al., 2009). Although pretreatment functions to boost sugar conversion yield, effectiveness of the chosen pretreatment should be comprehensively determined by all-sided criteria, including sugar loss, inhibitor formation, sugar conversion yield, and capital input.

\subsection{Thermochemical Conversion}

Thermochemical conversion technologies, including combustion, pyrolysis, and gasification, are commonly utilized to produce heat, power, bio-oil, and syngas from lignocellulosic biomass (Liu et al., 2017; Saidur et al., 2011). The absence or presence of oxygen is the crucial difference between combustion and pyrolysis. The thermochemical conversion of Miscanthus biomass is discussed in the next section.

\subsubsection{Heat and Power Generation}

It has been reported that more than $90 \%$ of the world's bioenergy was obtained from the direct combustion of lignocellulosic biomass due to its high maneuverability and economic characteristics (Vassilev et al., 2013), as shown in Figure 10.1.

The calorific value is one of the most important parameters of biomass intended for use as a source of energy. The calorific value can be determined as higher heating value (HHV) which is the amount of heat released during fuel combustion when all products are turned back to precombustion state $\left(25^{\circ} \mathrm{C}\right)$, so the heat of water condensation is included in value.

$M . \times$ giganteus elemental content and calorific value when the crop is produced at the regular agricultural land are summed up in Table 10.3 (Lewandowski et al., 2000) and Table 10.4 (Nebeska et al., 2019).

The use of Miscanthus biomass to produce heat and power, and the interconnection between combustion properties and agronomy practices (flowering, fertilization, senescence, and harvesting time), particle size, and genotypes are described (Baxter et al., 2012, 2014; Bilandzija et al., 2017; Clifton-Brown et al., 2004; Finnan \& Burke, 2016; Iqbal \& Lewandowski, 2016; Iqbal et al., 2017; Jensen et al., 2017; Lanzerstorfer, 2019; Meehan et al., 2013; Osman et al., 2017; Wilk et al., 2017). However, the presence of high quantities of alkali metal species in biomass ash often results in the formation of liquid phases such as alkali sulfates, silicates, and chlorides during combustion, which is responsible in slagging, fouling, corrosions, and agglomeration of bed material (Cruz et al., 2019; Morris et al., 2018; Nunes et al., 2016). In addition, the agglomeration severity is also related to operational variables, such 


\section{TABLE 10.3}

M. $\times$ giganteus Biomass Elemental Content and Calorific Value

\begin{tabular}{lcccc}
\hline Country & Austria & Germany & Denmark & Greece \\
\hline Age of stand (years) & 3 & 3 & $3-5$ & $2-3$ \\
Month of harvest & January/ & February/ & January/ & End of growing \\
& February & March & April & $\begin{array}{c}\text { season } \\
\text { Water content } \% \text { fresh water) }\end{array}$ \\
Ash (\% dry matter) & 2.79 & $16-28$ & $21-48$ & $38-44$ \\
N (\% dry matter) & 0.49 & $0.19-0.39$ & $0.58-0.67$ & 1.60 \\
P (\% dry matter) & - & - & & 0.33 \\
K (\% dry matter) & - & $0.52-0.94$ & $0.31-0.48$ & - \\
S (\% dry matter) & 0.04 & $0.07-0.10$ & - & - \\
Cl (\% dry matter) & 0.24 & $0.10-0.17$ & $0.04-0.12$ & - \\
C (\% dry matter) & 48.3 & $47.8-49.7$ & - & - \\
Calorific value $\left(\mathrm{MJ} \mathrm{kg}{ }^{-1}\right)$ & 19.12 & $17.05-18.54$ & - & - \\
\hline
\end{tabular}

Source: Modified from Lewandowski et al. (2000).

\section{TABLE 10.4}

The Calorific Value of Miscanthus Biomass While Produced in the Regular Agricultural Soil

\begin{tabular}{lccl}
\hline $\begin{array}{l}\text { Location of the } \\
\text { Miscanthus Plantation }\end{array}$ & Harvesting Time & HHV $\left(\mathbf{M J ~ k g} \mathbf{~ k}^{-1}\right)$ & \multicolumn{1}{c}{ Reference } \\
\hline Croatia & $\begin{array}{c}\text { Autumn \& winter \& } \\
\text { spring }\end{array}$ & $18.19 \pm 0.27^{\mathrm{b}}$ & Bilandzija et al. (2017) \\
France & $\mathrm{n} / \mathrm{d}$ & $17.80^{\mathrm{b}}$ & Jeguirim et al. (2010) \\
Germany & March & 17.74 & Michel et al. (2006) \\
Poland & July & $19.04^{\mathrm{b}}$ & Dukiewicz et al. (2014) \\
Spain & $\mathrm{n} / \mathrm{d}$ & $18.07 \pm 0.16^{\mathrm{b}}$ & García et al. (2012) \\
United Kingdom & October & $17.54 \pm 0.13^{\mathrm{a}}$ & Jensen et al. (2017) \\
United Kingdom & February & $17.58 \pm 0.05^{\mathrm{a}}$ & Jensen et al. (2017) \\
United Kingdom & September & $18.20^{\mathrm{a}}$ & Mos et al. (2013) \\
United Kingdom & February & $18.80^{\mathrm{a}}$ & Mos et al. (2013) \\
United Kingdom & February & $19.19 \pm 0.30^{\mathrm{a}}$ & Baxter et al. (2014) \\
\hline
\end{tabular}

Source: Modified from Nebeska et al. (2019).

a Calculation from ultimate analysis.

b Calorimetry.

as combustion temperature, fluidizing gas velocity, and additives (Morris et al., 2018). To date, ashes (bottom ash and fly ash) obtained after combustion are currently (around 70\%) landfilled (Cruz et al., 2019). To valorize biomass ash, the biomass will be treated through hot water washing before the combustion process to remove the problematic chemical elements from the biomass efficiently and reduce acid gas formation and corrosion in the boiler (Gudka et al., 2016). 
TABLE 10.5

Combustion Heats of $M . \times$ giganteus Biomass Produced at the Military Soil from Mimon (Czech Republic) and Control Soil

\begin{tabular}{lc}
\hline & HHV (MJ kg-1) \\
\hline Biomass from control soil & $17.30 \pm 0.2$ \\
Biomass from Mimon soil & $17.10 \pm 0.2$ \\
Other Fuels & \\
Dry wood (20\%) & 16.0 \\
Brown coal (from Most, Czech Republic) & $11.7-17.2$ \\
Black coal (from Ostrava, Czech Republic) & $22.8-29.2$ \\
Coke & 27.5 \\
Mineral oil & $40.6-42.3$ \\
Wheat straw & 15.5 \\
Paper & 14,1 \\
Waste plastics (separated) & 23.0 \\
Waste tires & 25.0 \\
\hline
\end{tabular}

Source: Modified from Nebeska et al. (2019).

In Table 10.5 the HHV value of $M . \times$ giganteus biomass produced at the military site (Mimon, Czech Republic) and control soil is presented (for sum: leaves+stems). The biomass was taken after 2 years of vegetation and harvested at the end of vegetation. In comparison, the amount of energy (combustion heat) obtained from burning of other fuels is summarized.

Even though the measuring was done for Miscanthus biomass that was not yet fully mature, the combustion energy was quite high, comparable to energy produced by wood or brown coal. When $M . \times$ giganteus was cultivated in Mimon soil, it had a slight negative effect on the value of combustion heat $(17.10 \pm 0.2$ for biomass from Mimon military soil compared to $17.30 \pm 0.2$ for biomass from control soil).

\subsubsection{Bio-Oil and Syngas Production}

Pyrolysis and gasification have attracted considerable attention to convert Miscanthus biomass into liquid bio-oil, solid biochar, and syngas (carbon dioxide, carbon monoxide, hydrogen, and hydrocarbons) (Jayaraman \& Gökalp, 2015). These are achieved by reacting the biomass at high temperatures (more than $400^{\circ} \mathrm{C}$ ), without combustion, with a controlled amount of oxygen and steam, as shown in Figure 10.1. During pyrolysis and gasification, a number of chemical reactions are involved in the formation of biooil and syngas, including dehydration, depolymerization, isomerization, aromatization, decarboxylation, and charring (Kan et al., 2016; Wang et al., 2017), which occur chaotically as the observation of transitional behavior through thermogravimetric analysis (Jayaraman \& Gökalp, 2015). The decomposition of biomass components was reported to vary: hemicellulose 
$\left(250^{\circ} \mathrm{C}-350^{\circ} \mathrm{C}\right)$, cellulose $\left(325^{\circ} \mathrm{C}-400^{\circ} \mathrm{C}\right)$, and lignin $\left(300^{\circ} \mathrm{C}-550^{\circ} \mathrm{C}\right)$ (Isahak et al., 2012; Kan et al., 2016). After fast pyrolysis, bio-oil, syngas, and biochar typically account for $60 \%-70 \%, 13 \%-25 \%$, and $12 \%-15 \%$, respectively (Isahak et al., 2012).

The yield and quality of bio-oil and syngas during pyrolysis or gasification can be determined by parent biomass (organic composition, inorganic impurities, harvesting time, senescence time, and genotype) and operational (pretreatment, temperature, size reduction, feed rate, gas flow rate, and catalytic type) factors (Banks et al., 2014; Bok et al., 2013; Dickerson \& Soria, 2013; Greenhalf et al., 2013; Heo et al., 2010; Kim et al., 2016; Kim et al., 2014; Melligan et al., 2011; Mos et al., 2013; Yorgun \& Şimşek, 2008, 2003). Although biomass inorganics remain predominantly in the biochar, the fraction ejected as well as fine biochar particles entrained can have drastic impacts on the bio-oil properties and product yields (Liu et al., 2017). Inorganic impurities create specific challenges ranging from corrosion and fouling of surfaces to rapid and permanent deactivation of catalysts (Liu et al., 2017). Moreover, the chemical interaction between hemicellulose and lignin induces the generation of lignin-derived phenols, limiting hydrocarbon formation (Wang et al., 2011), and the cross-link between lignin and cellulose has a negative influence on the formation and distribution of pyrolysis products (Hosoya et al., 2007).

In order to make the biomass amenable, mechanical refining, thermal (torrefaction, steam explosion, ultrasound, and microwave irradiation), chemical (acid, alkali, and ionic liquid), and biological (microbial consortium and enzymes) pretreatments have been widely proposed to enhance biomass conversion efficiency and quality of bio-oil and syngas (Kan et al., 2016; Wang et al., 2017). However, these are not reviewed in this chapter due to the limited available studies. Regardless of which pretreatment is used, the intrinsic mechanism is mainly to (i) modify structural characteristics and alter chemical composition by decomposing hemicellulose and disrupting lignin; (ii) increase energy density; (iii) eliminate mineral substance (ash content). From the intrinsic mechanism, $\mathrm{CO}_{2}$ and $\mathrm{CO}$ mainly derive from the degradation and recombination of carbonyl $(\mathrm{C}=\mathrm{O})$ and carboxyl (COO) groups (Qu et al., 2011), while $\mathrm{CH}_{4}$ is primarily ascribed to methoxyl $\left(-\mathrm{O}-\mathrm{CH}_{3}\right)$ and methylene $\left(-\mathrm{CH}_{2}-\right)$ groups and $\mathrm{H}_{2}$ results from aromatic $\mathrm{C}=\mathrm{C}$ and $\mathrm{C}-\mathrm{H}$ groups (Liu et al., 2008). Therefore, changes in cellulose, hemicellulose, and lignin content of biomass would cause elemental variation, thus influencing the final composition and quality of bio-oil and syngas during pyrolysis.

The application of bio-oil obtained from biomass pyrolysis as candidate combustion fuels for electricity and heat production has been extensively investigated (Kan et al., 2016). However, due to the poor quality (weak volatility, high viscosity, and high corrosiveness), its long-term operation in a diesel test engine is still unfeasible (Bridgwater, 1999). Therefore, further biorefining and upgrading of bio-oil using catalytic cracking technologies, highpressure hydroprocessing, steam reforming, and gasification are needed to 
render it matchable to engines (Butler et al., 2011; Kan et al., 2016). For syngas, it can be directly used for gas combustion in spark ignition and compression ignition engines as well as further biofuel synthesis (Qu et al., 2011).

\section{References}

Alam, A., Zhang, R., Liu, P., Huang, J., Wang, Y., Hu, Z., Madadi, M., Sun, D., Hu, R., Ragauskas, A. J., Tu, Y., \& Peng, L. (2019). A finalized determinant for complete lignocellulose enzymatic saccharification potential to maximize bioethanol production in bioenergy Miscanthus. Biotechnology for Biofuels, 12(1), 99. https:// doi.org/10.1186/s13068-019-1437-4

Arnoult, S., \& Brancourt-Hulmel, M. (2015). A review on Miscanthus biomass production and composition for bioenergy use: Genotypic and environmental variability and implications for breeding. Bioenergy Research, 8(2), 502-526. https:// doi.org/10.1007/s12155-014-9524-7

Arnoult, S., Mansard, M.-C., \& Brancourt-Hulmel, M. (2015). Early prediction of Miscanthus biomass production and composition based on the first six years of cultivation. Crop Science, 55(3), 1104-1116. https://doi.org/10.2135/ cropsci2014.07.0493

Auxenfans, T., Buchoux, S., Husson, E., \& Sarazin, C. (2014). Efficient enzymatic saccharification of Miscanthus: Energy-saving by combining dilute acid and ionic liquid pretreatments. Biomass and Bioenergy, 62, 82-92. https://doi.org/10.1016/j. biombioe.2014.01.011

Bailey, B. K. (2018). Performance of ethanol as a transportation fuel. In Charles E. Wyman (ed.), Handbook on Bioethanol (pp. 37-60). Routledge.

Banks, S. W., Nowakowski, D. J., \& Bridgwater, A. V. (2014). Fast pyrolysis processing of surfactant washed Miscanthus. Fuel Processing Technology, 128, 94-103. https://doi.org/10.1016/j.fuproc.2014.07.005

Baxter, X. C., Darvell, L. I., Jones, J. M., Barraclough, T., Yates, N. E., \& Shield, I. (2012). Study of Miscanthus $\times$ giganteus ash composition - Variation with agronomy and assessment method. Fuel, 95, 50-62. https://doi.org/10.1016/j.fuel.2011.12.025

Baxter, X. C., Darvell, L. I., Jones, J. M., Barraclough, T., Yates, N. E., \& Shield, I. (2014). Miscanthus combustion properties and variations with Miscanthus agronomy. Fuel, 117(PART A), 851-869. https://doi.org/10.1016/j.fuel.2013.09.003

Bilandzija, N., Jurisic, V., Voca, N., Leto, J., Matin, A., Sito, S., \& Kricka, T. (2017). Combustion properties of Miscanthus $\times$ giganteus biomass - Optimization of harvest time. Journal of the Energy Institute, 90(4), 528-533. https://doi.org/10.1016/j. joei.2016.05.009

Boakye-Boaten, N. A., Xiu, S., Shahbazi, A., \& Fabish, J. (2015). Liquid hot water pretreatment of Miscanthus $\times$ giganteus for the sustainable production of bioethanol. BioResources, 10(3), 5890-5905.

Boakye-Boaten, N. A., Xiu, S., Shahbazi, A., Wang, L., Li, R., Mims, M., \& Schimmel, K. (2016). Effects of fertilizer application and dry/wet processing of Miscanthus $\times$ giganteus on bioethanol production. Bioresource Technology, 204, 98-105. https:// doi.org/10.1016/j.biortech.2015.12.070 
Bok, J. P., Choi, H. S., Choi, J. W., \& Choi, Y. S. (2013). Fast pyrolysis of Miscanthus sinensis in fluidized bed reactors: Characteristics of product yields and biocrude oil quality. Energy, 60, 44-52. https://doi.org/10.1016/j.energy.2013.08.024

Bridgwater, A. V. (1999). Principles and practice of biomass fast pyrolysis processes for liquids. Journal of Analytical and Applied Pyrolysis, 51(1), 3-22. https://doi. org/10.1016/S0165-2370(99)00005-4

Brosse, N., Dufour, A., Meng, X., Sun, Q., \& Ragauskas, A. (2012). Miscanthus: A fastgrowing crop for biofuels and chemicals production. Biofuels, Bioproducts and Biorefining, 6(5), 580-598. https://doi.org/10.1002/bbb.1353

Brosse, N., Sannigrahi, P., \& Ragauskas, A. (2009). Pretreatment of Miscanthus $\times$ giganteus using the ethanol organosolv process for ethanol production. Industrial and Engineering Chemistry Research, 48(18), 8328-8334. https://doi.org/10.1021/ ie9006672

Butler, E., Devlin, G., Meier, D., \& McDonnell, K. (2011). A review of recent laboratory research and commercial developments in fast pyrolysis and upgrading. Renewable and Sustainable Energy Reviews, 15(8), 4171-4186. https://doi. org/10.1016/j.rser.2011.07.035

Cerazy-Waliszewska, J., Jeżowski, S., Łysakowski, P., Waliszewska, B., Zborowska, M., Sobańska, K., Ślusarkiewicz-Jarzina, A., Białas, W., \& Pniewski, T. (2019). Potential of bioethanol production from biomass of various Miscanthus genotypes cultivated in three-year plantations in west-central Poland. Industrial Crops and Products, 141, 111790. https://doi.org/10.1016/j.indcrop.2019.111790

Cha, Y., An, G. H., Yang, J., Moon, Y., Yu, G., \& Ahn, J. (2015a). Bioethanol production from Miscanthus using thermotolerant Saccharomyces cerevisiae MBC 2 isolated from the respiration-deficient mutants. Renewable Energy, 80, 259-265. https:// doi.org/10.1016/j.renene.2015.02.016

Cha, Y., Yang, J., Park, Y., An, G. H., Ahn, J., Moon, Y., Yoon, Y., Yu, G., \& Choi, I. (2015b). Continuous alkaline pretreatment of Miscanthus sacchariflorus using a bench-scale single screw reactor. Bioresource Technology, 181, 338-344. https:// doi.org/10.1016/j.biortech.2015.01.079

Chen, X., Kuhn, E., Jennings, E. W., Nelson, R., Tao, L., Zhang, M., \& Tucker, M. P. (2016). DMR (deacetylation and mechanical refining) processing of corn stover achieves high monomeric sugar concentrations $\left(230 \mathrm{~g} \mathrm{~L}^{-1}\right)$ during enzymatic hydrolysis and high ethanol concentrations $(>10 \% \mathrm{v} / \mathrm{v})$ during fermentation without hydrolysate purification or concentration. Energy and Environmental Science, 9(4), 1237-1245. https://doi.org/10.1039/c5ee03718b

Clifton-Brown, J. C., Stampfl, P. F., \& Jones, M. B. (2004). Miscanthus biomass production for energy in Europe and its potential contribution to decreasing fossil fuel carbon emissions. Global Change Biology, 10(4), 509-518. https://doi. org/10.1111/j.1529-8817.2003.00749.x

Cruz, N. C., Silva, F. C., Tarelho, L. A. C., \& Rodrigues, S. M. (2019). Critical review of key variables affecting potential recycling applications of ash produced at large-scale biomass combustion plants. Resources, Conservation and Recycling, 150, 104427. https://doi.org/10.1016/j.resconrec.2019.104427

Damartzis, T., \& Zabaniotou, A. (2011). Thermochemical conversion of biomass to second generation biofuels through integrated process design-A review. Renewable and Sustainable Energy Reviews, 15(1), 366-378. https://doi.org/10.1016/j. rser.2010.08.003 
Danielewicz, D., Surma-Slusarska, B., Żurek, G., \& Martyniak, D., (2015). Selected grass plants as biomass fuels and raw material for papermaking. Part I. Caloritic valve and chemical composition. BioResources, 10(4), 8539-8551. https://doi. org/10.15375/biores.10.4.8539-8851

Dash, M., \& Mohanty, K. (2019). Effect of different ionic liquids and anti-solvents on dissolution and regeneration of Miscanthus towards bioethanol. Biomass and Bioenergy, 124, 33-42. https://doi.org/10.1016/j.biombioe.2019.03.006

de Vrije, T., Bakker, R. R., Budde, M. A. W., Lai, M. H., Mars, A. E., \& Claassen, P. A. M. (2009). Efficient hydrogen production from the lignocellulosic energy crop Miscanthus by the extreme thermophilic bacteria Caldicellulosiruptor saccharolyticus and Thermotoga neapolitana. Biotechnology for Biofuels, 2(1), 1-15. https:// doi.org/10.1186/1754-6834-2-12

de Vrije, T., de Haas, G., Tan, G. B., Keijsers, E. R. P., \& Claassen, P. A. M. (2002). Pretreatment of Miscanthus for hydrogen production by Thermotoga elfii. International Journal of Hydrogen Energy, 27(11-12), 1381-1390. https://doi. org/10.1016/S0360-3199(02)00124-6

Dickerson, T., \& Soria, J. (2013). Catalytic fast pyrolysis: A review. Energies, 6(1), 514-538. https://doi.org/10.3390/en6010514

Dukiewicz, H., Waliszewska, B., \& Zborowska, M. (2014). Higher and lower heating values of selected lignocellulose materials. Annals of Warsaw University of Life Sciences - SGGW, Forestry and Wood Technology, 87, 60-63.

Finnan, J., \& Burke, B. (2016). Nitrogen fertilization of Miscanthus $\times$ giganteus: Effects on nitrogen uptake, growth, yield and emissions from biomass combustion. Nutrient Cycling in Agroecosystems, 106(2), 249-256. https://doi.org/10.1007/s10705-016-9793-y

Frigon, J. C., \& Guiot, S. R. (2010). Biomethane production from starch and lignocellulosic crops: A comparative review. Biofuels, Bioproducts and Biorefining, 4(4), 447-458. https://doi.org/10.1002/bbb.229

Frydendal-Nielsen, S., Hjorth, M., Baby, S., Felby, C., Jørgensen, U., \& Gislum, R. (2016). The effect of harvest time, dry matter content and mechanical pretreatments on anaerobic digestion and enzymatic hydrolysis of miscanthus. Bioresource Technology, 218, 1008-1015. https://doi.org/10.1016/j.biortech.2016.07.046

García, R., Pizarro, C., Lavín, A. G., \& Bueno, J. L. (2012). Characterization of Spanish biomass wastes for energy use. Bioresource Technology, 103(1), 249-258. https:// doi.org/10.1016/j.biortech.2011.10.004

Ge, X., Xu, F., Vasco-Correa, J., \& Li, Y. (2016). Giant reed: A competitive energy crop in comparison with miscanthus. Renewable and Sustainable Energy Reviews, 54, 350-362. https://doi.org/10.1016/j.rser.2015.10.010

Greenhalf, C. E., Nowakowski, D. J., Yates, N., Shield, I., \& Bridgwater, A. V. (2013). The influence of harvest and storage on the properties of and fast pyrolysis products from Miscanthus $\times$ giganteus. Biomass and Bioenergy, 56, 247-259. https://doi. org/10.1016/j.biombioe.2013.05.007

Gudka, B., Jones, J. M., Lea-Langton, A. R., Williams, A., \& Saddawi, A. (2016). A review of the mitigation of deposition and emission problems during biomass combustion through washing pre-treatment. Journal of the Energy Institute, 89(2), 159-171. https://doi.org/10.1016/j.joei.2015.02.007

Guo, X. M., Trably, E., Latrille, E., Carrre, H., \& Steyer, J. P. (2010). Hydrogen production from agricultural waste by dark fermentation: A review. International Journal of Hydrogen Energy, 35(19), 10660-10673. https://doi.org/10.1016/j.ijhydene.2010.03.008 
Han, M., Kim, Y., Koo, B., \& Choi, G. (2011). Bioethanol production by Miscanthus as a lignocellulosic biomass: Focus on high efficiency conversion to glucose and ethanol. BioResources, 6(2), 1939-1953.

Han, M., Moon, S. K., \& Choi, G. W. (2014). Pretreatment solution recycling and high-concentration output for economical production of bioethanol. Bioprocess and Biosystems Engineering, 37(11), 2205-2213. https://doi.org/10.1007/ s00449-014-1198-1

Hastings, A., Clifton-Brown, J., Wattenbach, M., Mitchell, C. P., Stampfl, P., \& Smith, P. (2009). Future energy potential of Miscanthus in Europe. GCB Bioenergy, 1(2), 180-196. https://doi.org/10.1111/j.1757-1707.2009.01012.x

Heaton, E. A., Dohleman, F. G., \& Long, S. P. (2008). Meeting US biofuel goals with less land: The potential of Miscanthus. Global Change Biology, 14(9), 2000-2014. https://doi.org/10.1111/j.1365-2486.2008.01662.x

Hendriks, A. T. W. M., \& Zeeman, G. (2009). Pretreatments to enhance the digestibility of lignocellulosic biomass. Bioresource Technology, 100(1), 10-18. https://doi. org/10.1016/j.biortech.2008.05.027

Heo, H. S., Park, H. J., Yim, J. H., Sohn, J. M., Park, J., Kim, S. S., Ryu, C., Jeon, J. K., \& Park, Y. K. (2010). Influence of operation variables on fast pyrolysis of Miscanthus sinensis var. purpurascens. Bioresource Technology, 101(10), 3672-3677. https://doi. org/10.1016/j.biortech.2009.12.078

Ho, M. C., Ong, V. Z., \& Wu, T. Y. (2019). Potential use of alkaline hydrogen peroxide in lignocellulosic biomass pretreatment and valorization - A review. Renewable and Sustainable Energy Reviews, 112, 75-86. https://doi.org/10.1016/j. rser.2019.04.082

Hodgson, E. M., Fahmi, R., Yates, N., Barraclough, T., Shield, I., Allison, G., Bridgwater, A. V., \& Donnison, I. S. (2010). Miscanthus as a feedstock for fast-pyrolysis: Does agronomic treatment affect quality? Bioresource Technology, 101(15), 6185-6191. https://doi.org/10.1016/j.biortech.2010.03.024

Hosoya, T., Kawamoto, H., \& Saka, S. (2007). Cellulose-hemicellulose and cellulose-lignin interactions in wood pyrolysis at gasification temperature. Journal of Analytical and Applied Pyrolysis, 80(1), 118-125. https://doi.org/10.1016/j. jaap.2007.01.006

Iqbal, Y., Kiesel, A., Wagner, M., Nunn, C., Kalinina, O., Hastings, A. F. S. J., CliftonBrown, J. C., \& Lewandowski, I. (2017). Harvest time optimization for combustion quality of different Miscanthus genotypes across Europe. Frontiers in Plant Science, 8, 727. https://doi.org/10.3389/fpls.2017.00727

Iqbal, Y., \& Lewandowski, I. (2014). Inter-annual variation in biomass combustion quality traits over five years in fifteen Miscanthus genotypes in south Germany. Fuel Processing Technology, 121, 47-55. https://doi.org/10.1016/j.fuproc.2014.01.003

Iqbal, Y., \& Lewandowski, I. (2016). Biomass composition and ash melting behaviour of selected miscanthus genotypes in Southern Germany. Fuel, 180, 606-612. https://doi.org/10.1016/j.fuel.2016.04.073

Isahak, W. N. R. W., Hisham, M. W. M., Yarmo, M. A., \& Yun Hin, T. Y. (2012). A review on bio-oil production from biomass by using pyrolysis method. Renewable and Sustainable Energy Reviews, 16(8), 5910-5923. https://doi.org/10.1016/j. rser.2012.05.039

Jayaraman, K., \& Gökalp, I. (2015). Pyrolysis, combustion and gasification characteristics of miscanthus and sewage sludge. Energy Conversion and Management, 89, 83-91. https://doi.org/10.1016/j.enconman.2014.09.058 
Jeguirim, M., Dorge, S., \& Trouvé, G. (2010). Thermogravimetric analysis and emission characteristics of two energy crops in air atmosphere: Arundo donax and Miscanthus giganteus. Bioresource Technology, 101(2), 788-793. https://doi. org/10.1016/j.biortech.2009.05.063

Jensen, E., Robson, P., Farrar, K., Thomas Jones, S., Clifton-Brown, J., Payne, R., \& Donnison, I. (2017). Towards Miscanthus combustion quality improvement: The role of flowering and senescence. GCB Bioenergy, 9(5), 891-908. https://doi. org/10.1111/gcbb.12391

Ji, Z., Zhang, X., Ling, Z., Zhou, X., Ramaswamy, S., \& Xu, F. (2015). Visualization of Miscanthus $\times$ giganteus cell wall deconstruction subjected to dilute acid pretreatment for enhanced enzymatic digestibility. Biotechnology for Biofuels, 8(1), 1-14. https://doi.org/10.1186/s13068-015-0282-3

Jurado, E., Gavala, H. N., \& Skiadas, I. V. (2013). Enhancement of methane yield from wheat straw, miscanthus and willow using aqueous ammonia soaking. Environmental Technology (United Kingdom), 34(13-14), 2069-2075. https://doi.org /10.1080/09593330.2013.826701

Kan, T., Strezov, V., \& Evans, T. J. (2016). Lignocellulosic biomass pyrolysis: A review of product properties and effects of pyrolysis parameters. Renewvable and Sustainable Energy Reviews, 57, 1126-1140. https://doi.org/10.1016/j.rser.2015.12.185

Kang, K. E., Han, M., Moon, S. K., Kang, H. W., Kim, Y., Cha, Y. L., \& Choi, G. W. (2013). Optimization of alkali-extrusion pretreatment with twin-screw for bioethanol production from Miscanthus. Fuel, 109, 520-526. https://doi.org/10.1016/j. fuel.2013.03.026

Katukuri, N. R., Fu, S., He, S., Xu, X., Yuan, X., Yang, Z., \& Guo, R. B. (2017). Enhanced methane production of Miscanthus floridulus by hydrogen peroxide pretreatment. Fuel, 199, 562-566. https://doi.org/10.1016/j.fuel.2017.03.014

Khullar, E., Dien, B. S., Rausch, K. D., Tumbleson, M. E., \& Singh, V. (2013). Effect of particle size on enzymatic hydrolysis of pretreated Miscanthus. Industrial Crops and Products, 44, 11-17. https://doi.org/10.1016/j.indcrop.2012.10.015

Kiesel, A., \& Lewandowski, I. (2017). Miscanthus as biogas substrate - cutting tolerance and potential for anaerobic digestion. GCB Bioenergy, 9(1), 153-167. https:// doi.org/10.1111/gcbb.12330

Kim, J. S., Lee, Y. Y., \& Kim, T. H. (2016). A review on alkaline pretreatment technology for bioconversion of lignocellulosic biomass. Bioresource Technology, 199, 42-48. https://doi.org/10.1016/j.biortech.2015.08.085

Kim, J. Y., Oh, S., Hwang, H., Moon, Y. H., \& Choi, J. W. (2014). Assessment of miscanthus biomass (Miscanthus sacchariflorus) for conversion and utilization of bio-oil by fluidized bed type fast pyrolysis. Energy, 76, 284-291. https://doi. org/10.1016/j.energy.2014.08.010

Kim, S. J., Kim, M. Y., Jeong, S. J., Jang, M. S., \& Chung, I. M. (2012). Analysis of the biomass content of various Miscanthus genotypes for biofuel production in Korea. Industrial Crops and Products, 38(1), 46-49. https://doi.org/10.1016/j. indcrop.2012.01.003

Kim, T., Im, D., Oh, K., \& Kim, T. (2018). Effects of organosolv pretreatment using temperature-controlled bench-scale ball milling on enzymatic saccharification of Miscanthus $\times$ giganteus. Energies, 11(10), 2657. https://doi.org/10.3390/en11102657

Klimiuk, E., Pokój, T., Budzyński, W., \& Dubis, B. (2010). Theoretical and observed biogas production from plant biomass of different fibre contents. Bioresource Technology, 101(24), 9527-9535. https://doi.org/10.1016/j.biortech.2010.06.130 
Kristensen, J. B., Felby, C., \& Jørgensen, H. (2009). Yield-determining factors in highsolids enzymatic hydrolysis of lignocellulose. Biotechnology for Biofuels, 2(1), 1-10. https://doi.org/10.1186/1754-6834-2-11

Lanzerstorfer, C. (2019). Combustion of Miscanthus: Composition of the ash by particle size. Energies, 12(1), 178. https://doi.org/10.3390/en12010178

Le Ngoc Huyen, T., Rémond, C., Dheilly, R. M., \& Chabbert, B. (2010). Effect of harvesting date on the composition and saccharification of Miscanthus $\times$ giganteus. Bioresource Technology, 101(21), 8224-8231. https://doi.org/10.1016/j.biortech.2010.05.087

Lee, W.-C., \& Kuan, W.-C. (2015). Miscanthus as cellulosic biomass for bioethanol production. Biotechnology Journal, 10(6), 840-854. https://doi.org/10.1002/ biot.201400704

Lewandowski, I., Clifton-Brown, J. C., Scurlock, J. M. O., \& Huisman, W. (2000). Miscanthus: European experience with a novel energy crop. Biomass and Bioenergy, 19(4), 209-227. https://doi.org/10.1016/S0961-9534(00)00032-5

Li, C., Liu, G., Nges, I. A., \& Liu, J. (2016). Enhanced biomethane production from Miscanthus lutarioriparius using steam explosion pretreatment. Fuel, 179, 267-273. https://doi.org/10.1016/j.fuel.2016.03.087

Li, H. Q., Li, C. L., Sang, T., \& Xu, J. (2013). Pretreatment on Miscanthus lutarioriparious by liquid hot water for efficient ethanol production. Biotechnology for Biofuels, 6(1), 1-10. https://doi.org/10.1186/1754-6834-6-76

Liu, Q., Chmely, S. C., \& Abdoulmoumine, N. (2017). Biomass treatment strategies for thermochemical conversion. Energy and Fuels, 31(4), 3525-3536. https://doi. org/10.1021/acs.energyfuels.7b00258

Liu, Q., Wang, S., Zheng, Y., Luo, Z., \& Cen, K. (2008). Mechanism study of wood lignin pyrolysis by using TG-FTIR analysis. Journal of Analytical and Applied Pyrolysis, 82(1), 170-177. https://doi.org/10.1016/j.jaap.2008.03.007

Mangold, A., Lewandowski, I., Hartung, J., \& Kiesel, A. (2019). Miscanthus for biogas production: Influence of harvest date and ensiling on digestibility and methane hectare yield. GCB Bioenergy, 11(1), 50-62. https://doi.org/10.1111/gcbb.12584

Meehan, P. G., Finnan, J. M., \& Mc Donnell, K. P. (2013). The effect of harvest date and harvest method on the combustion characteristics of Miscanthus $\times$ giganteus. GCB Bioenergy, 5(5), 487-496. https://doi.org/10.1111/gcbb.12003

Melligan, F., Auccaise, R., Novotny, E. H., Leahy, J. J., Hayes, M. H. B., \& Kwapinski, W. (2011). Pressurised pyrolysis of Miscanthus using a fixed bed reactor. Bioresource Technology, 102(3), 3466-3470. https://doi.org/10.1016/j.biortech.2010.10.129

Menardo, S., Bauer, A., Theuretzbacher, F., Piringer, G., Nilsen, P. J., Balsari, P., Pavliska, O., \& Amon, T. (2013). Biogas production from steam-exploded miscanthus and utilization of biogas energy and $\mathrm{CO}_{2}$ in greenhouses. Bioenergy Research, 6(2), 620-630. https://doi.org/10.1007/s12155-012-9280-5

Michalska, K., Bizukojć, M., \& Ledakowicz, S. (2015). Pretreatment of energy crops with sodium hydroxide and cellulolytic enzymes to increase biogas production. Biomass and Bioenergy, 80, 213-221. https://doi.org/10.1016/j.biombioe.2015.05.022

Michel, R., Mischler, N., Azambre, B., Finqueneisel, G., Machnikowski, J., Rutkowski, P., Zimny, T., \& Weber, J. V. (2006). Miscanthus $\times$ giganteus straw and pellets as sustainable fuels and raw material for activated carbon. Environmental Chemistry Letters, 4(4), 185-189. https://doi.org/10.1007/s10311-006-0043-4

Morris, J. D., Daood, S. S., Chilton, S., \& Nimmo, W. (2018). Mechanisms and mitigation of agglomeration during fluidized bed combustion of biomass: A review. Fuel, 230, 452-473. https://doi.org/10.1016/j.fuel.2018.04.098 
Mos, M., Banks, S. W., Nowakowski, D. J., Robson, P. R. H., Bridgwater, A. V., \& Donnison, I. S. (2013). Impact of Miscanthus $\times$ giganteus senescence times on fast pyrolysis bio-oil quality. Bioresource Technology, 129, 335-342. https://doi. org/10.1016/j.biortech.2012.11.069

Mosier, N., Wyman, C., Dale, B., Elander, R., Lee, Y. Y., Holtzapple, M., \& Ladisch, M. (2005). Features of promising technologies for pretreatment of lignocellulosic biomass. Bioresource Technology, 96(6), 673-686. https://doi.org/10.1016/j. biortech.2004.06.025

Nebeska, D., Trogl, J., Zofkova, D., Voslarova, A., Stojdl, J., \& Pidlisnyuk, V. (2019). Calorific values of Miscanthus $\times$ giganteus biomass cultivated under suboptimal conditions in marginal soils. Studia Oecologica, 13(1), 61-67. https://doi. org/10.21062/ujep/429.2020/a/1802-212X/SO/13/1/61

Nges, I. A., Li, C., Wang, B., Xiao, L., Yi, Z., \& Liu, J. (2016). Physio-chemical pretreatments for improved methane potential of Miscanthus lutarioriparius. Fuel, 166, 29-35. https://doi.org/10.1016/j.fuel.2015.10.108

Nunes, L. J. R., Matias, J. C. O., \& Catalão, J. P. S. (2016). Biomass combustion systems: A review on the physical and chemical properties of the ashes. Renewable and Sustainable Energy Reviews, 53, 235-242. https://doi.org/10.1016/j. rser.2015.08.053

Osman, A. I., Abdelkader, A., Johnston, C. R., Morgan, K., \& Rooney, D. W. (2017). Thermal investigation and kinetic modeling of lignocellulosic biomass combustion for energy production and other applications. Industrial and Engineering Chemistry Research, 56(42), 12119-12130. https://doi.org/10.1021/acs.iecr.7b03478

Padmanabhan, S., Kim, M., Blanch, H. W., \& Prausnitz, J. M. (2011). Solubility and rate of dissolution for Miscanthus in hydrophilic ionic liquids. Fluid Phase Equilibria, 309(1), 89-96. https://doi.org/10.1016/j.fluid.2011.06.034

Qu, T., Guo, W., Shen, L., Xiao, J., \& Zhao, K. (2011). Experimental study of biomass pyrolysis based on three major components: Hemicellulose, cellulose, and lignin. Industrial and Engineering Chemistry Research, 50(18), 10424-10433. https:// doi.org/10.1021/ie1025453

Rodríguez, H., Padmanabhan, S., Poon, G., \& Prausnitz, J. M. (2011). Addition of ammonia and/or oxygen to an ionic liquid for delignification of miscanthus. Bioresource Technology, 102(17), 7946-7952. https://doi.org/10.1016/j. biortech.2011.05.039

Saidur, R., Abdelaziz, E. A., Demirbas, A., Hossain, M. S., \& Mekhilef, S. (2011). A review on biomass as a fuel for boilers. Renewable and Sustainable Energy Reviews, 15(5), 2262-2289. https://doi.org/10.1016/j.rser.2011.02.015

Schmidt, A., Lemaigre, S., Ruf, T., Delfosse, P., \& Emmerling, C. (2018). Miscanthus as biogas feedstock: Influence of harvest time and stand age on the biochemical methane potential (BMP) of two different growing seasons. Biomass Conversion and Biorefinery, 8(2), 245-254. https://doi.org/10.1007/s13399-017-0274-6

Scordia, D., Cosentino, S. L., \& Jeffries, T. W. (2013). Effectiveness of dilute oxalic acid pretreatment of Miscanthus $\times$ giganteus biomass for ethanol production. Biomass and Bioenergy, 59, 540-548. https://doi.org/10.1016/j.biombioe.2013.09.011

Si, S., Chen, Y., Fan, C., Hu, H., Li, Y., Huang, J., Liao, H., Hao, B., Li, Q., Peng, L., \& Tu, Y. (2015). Lignin extraction distinctively enhances biomass enzymatic saccharification in hemicelluloses-rich Miscanthus species under various alkali and acid pretreatments. Bioresource Technology, 183, 248-254. https://doi. org/10.1016/j.biortech.2015.02.031 
Sørensen, A., Teller, P. J., Hilstrøm, T., \& Ahring, B. K. (2008). Hydrolysis of Miscanthus for bioethanol production using dilute acid presoaking combined with wet explosion pre-treatment and enzymatic treatment. Bioresource Technology, 99(14), 6602-6607. https://doi.org/10.1016/j.biortech.2007.09.091

Sun, S., Sun, S., Cao, X., \& Sun, R. (2016). The role of pretreatment in improving the enzymatic hydrolysis of lignocellulosic materials. Bioresource Technology, 199, 49-58. https://doi.org/10.1016/j.biortech.2015.08.061

Updegraff, D. M. (1969). Semimicro determination of cellulose inbiological materials. Analytical Biochemistry, 32(3), 420-424. https://doi.org/10.1016/ S0003-2697(69)80009-6

Vanderghem, C., Brostaux, Y., Jacquet, N., Blecker, C., \& Paquot, M. (2012). Optimization of formic/acetic acid delignification of Miscanthus $\times$ giganteus for enzymatic hydrolysis using response surface methodology. Industrial Crops and Products, 35(1), 280-286. https://doi.org/10.1016/j.indcrop.2011.07.014

Vasco-Correa, J., Ge, X., \& Li, Y. (2016). Fungal pretreatment of non-sterile miscanthus for enhanced enzymatic hydrolysis. Bioresource Technology, 203, 118-123. https:// doi.org/10.1016/j.biortech.2015.12.018

Vasco-Correa, J., \& Li, Y. (2015). Solid-state anaerobic digestion of fungal pretreated Miscanthus sinensis harvested in two different seasons. Bioresource Technology, 185, 211-217. https://doi.org/10.1016/j.biortech.2015.02.099

Vassilev, S. V., Baxter, D., \& Vassileva, C. G. (2013). An overview of the behaviour of biomass during combustion: Part I. Phase-mineral transformations of organic and inorganic matter. Fuel, 112, 391-449. https://doi.org/10.1016/j.fuel.2013.05.043

von Blottnitz, H., \& Curran, M. A. (2007). A review of assessments conducted on bioethanol as a transportation fuel from a net energy, greenhouse gas, and environmental life cycle perspective. Journal of Cleaner Production, 15(7), 607-619. https://doi.org/10.1016/j.jclepro.2006.03.002

Wagner, M., Mangold, A., Lask, J., Petig, E., Kiesel, A., \& Lewandowski, I. (2019). Economic and environmental performance of miscanthus cultivated on marginal land for biogas production. GCB Bioenergy, 11(1), 34-49. https://doi. org/10.1111/gcbb.12567

Wahid, R., Nielsen, S. F., Hernandez, V. M., Ward, A. J., Gislum, R., Jørgensen, U., \& Møller, H. B. (2015). Methane production potential from Miscanthus sp.: Effect of harvesting time, genotypes and plant fractions. Biosystems Engineering, 133, 71-80. https://doi.org/10.1016/j.biosystemseng.2015.03.005

Wang, B., Wang, X., \& Feng, H. (2010). Deconstructing recalcitrant Miscanthus with alkaline peroxide and electrolyzed water. Bioresource Technology, 101(2), 752-760. https://doi.org/10.1016/j.biortech.2009.08.063

Wang, S., Dai, G., Yang, H., \& Luo, Z. (2017). Lignocellulosic biomass pyrolysis mechanism: A state-of-the-art review. Progress in Energy and Combustion Science, 62, 33-86. https://doi.org/10.1016/j.pecs.2017.05.004

Wang, S., Guo, X., Wang, K., \& Luo, Z. (2011). Influence of the interaction of components on the pyrolysis behavior of biomass. Journal of Analytical and Applied Pyrolysis, 91(1), 183-189. https://doi.org/10.1016/j.jaap.2011.02.006

Wilk, M., Magdziarz, A., Gajek, M., Zajemska, M., Jayaraman, K., \& Gokalp, I. (2017). Combustion and kinetic parameters estimation of torrefied pine, acacia and Miscanthus $\times$ giganteus using experimental and modelling techniques. Bioresource Technology, 243, 304-314. https://doi.org/10.1016/j.biortech.2017.06.116 
Wyman, C. E. (2008). Cellulosic ethanol: A unique sustainable liquid transportation fuel. MRS Bulletin, 33(4), 381-383. https://doi.org/10.1557/mrs2008.77

Yang, F., Afzal, W., Cheng, K., Liu, N., Pauly, M., Bell, A. T., Liu, Z., \& Prausnitz, J. M. (2015a). Nitric-acid hydrolysis of Miscanthus $\times$ giganteus to sugars fermented to bioethanol. Biotechnology and Bioprocess Engineering, 20(2), 304-314. https://doi. org/10.1007/s12257-014-0658-4

Yang, S. J., Yoo, H. Y., Choi, H. S., Lee, J. H., Park, C., \& Kim, S. W. (2015b). Enhancement of enzymatic digestibility of Miscanthus by electron beam irradiation and chemical combined treatments for bioethanol production. Chemical Engineering Journal, 275, 227-234. https://doi.org/10.1016/j.cej.2015.04.056

Yeh, R. H., Lin, Y. S., Wang, T. H., Kuan, W. C., \& Lee, W. C. (2016). Bioethanol production from pretreated Miscanthus floridulus biomass by simultaneous saccharification and fermentation. Biomass and Bioenergy, 94, 110-116. https://doi. org/10.1016/j.biombioe.2016.08.009

Yoo, H. Y., Yang, X., Kim, D. S., Lee, S. K., Lotrakul, P., Prasongsuk, S., Punnapayak, H., \& Kim, S. W. (2016). Evaluation of the overall process on bioethanol production from miscanthus hydrolysates obtained by dilute acid pretreatment. Biotechnology and Bioprocess Engineering, 21(6), 733-742. https://doi.org/10.1007/ s12257-016-0485-x

Yorgun, S., \& Şimşek, Y. E. (2003). Fixed-bed pyrolysis of Miscanthus $\times$ giganteus: Product yields and bio-oil characterization. Energy Sources, 25(8), 779-790. https://doi.org/10.1080/00908310390207828

Yorgun, S., \& Şimşek, Y. E. (2008). Catalytic pyrolysis of Miscanthus $\times$ giganteus over activated alumina. Bioresource Technology, 99(17), 8095-8100. https://doi. org/10.1016/j.biortech.2008.03.036

Zhao, J., Xu, Y., Wang, W., Griffin, J., \& Wang, D. (2020a). Conversion of liquid hot water, acid and alkali pretreated industrial hemp biomasses to bioethanol. Bioresource Technology, 309, 123383. https://doi.org/10.1016/j.biortech.2020.123383

Zhao, J., Xu, Y., Zhang, M., \& Wang, D. (2020b). Integrating bran starch hydrolysates with alkaline pretreated soft wheat bran to boost sugar concentration. Bioresource Technology, 302, 122826. https://doi.org/10.1016/j.biortech.2020.122826

Zhou, X., Li, Q., Zhang, Y., \& Gu, Y. (2017). Effect of hydrothermal pretreatment on Miscanthus anaerobic digestion. Bioresource Technology, 224, 721-726. https:// doi.org/10.1016/j.biortech.2016.10.085

Zhu, Z., Macquarrie, D. J., Simister, R., Gomez, L. D., \& McQueen-Mason, S. J. (2015). Microwave assisted chemical pretreatment of Miscanthus under different temperature regimes. Sustainable Chemical Processes, 3(1), 1-13. https://doi. org/10.1186/s40508-015-0041-6

Ziolkowska, J. R. (2014). Prospective technologies, feedstocks and market innovations for ethanol and biodiesel production in the US. Biotechnology Reports, 4, 94-98. https://doi.org/10.1016/j.btre.2014.09.001

Zub, H. W., \& Brancourt-Hulmel, M. (2010). Agronomic and physiological performances of different species of Miscanthus, a major energy crop. A review. Agronomy for Sustainable Development, 30(2), 201-214. https://doi.org/10.1051/agro/2009034 